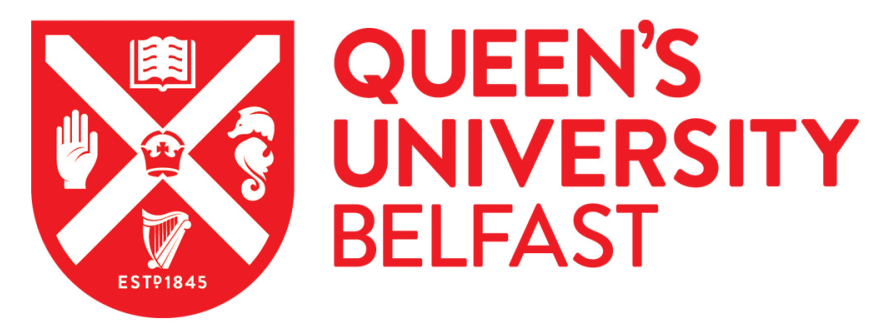

\title{
Capitalism as Affective Atmosphere: The Noir Worlds of Massimo Carlotto
}

Pepper, A. (2020). Capitalism as Affective Atmosphere: The Noir Worlds of Massimo Carlotto. In C. Breu, \& E. A. Hatmaker (Eds.), Noir Affect Fordham University Press.

\section{Published in:}

Noir Affect

\section{Document Version:}

Peer reviewed version

Queen's University Belfast - Research Portal:

Link to publication record in Queen's University Belfast Research Portal

\section{Publisher rights}

Copyright 2019 Fordham University Press. This work is made available online in accordance with the publisher's policies. Please refer to any applicable terms of use of the publisher.

\section{General rights}

Copyright for the publications made accessible via the Queen's University Belfast Research Portal is retained by the author(s) and / or other copyright owners and it is a condition of accessing these publications that users recognise and abide by the legal requirements associated with these rights.

Take down policy

The Research Portal is Queen's institutional repository that provides access to Queen's research output. Every effort has been made to ensure that content in the Research Portal does not infringe any person's rights, or applicable UK laws. If you discover content in the Research Portal that you believe breaches copyright or violates any law, please contact openaccess@qub.ac.uk. 


\title{
Capitalism as Affective Atmosphere: The Noir Worlds of Massimo Carlotto \\ Andrew Pepper
}

\begin{abstract}
:
This essay seeks to interrogate the relationship between the novels of the Italian crime writer Massimo Carlotto and the ills of capitalism in its neoliberal phase. But crucially it is not an ideological critique where character and action can be fully explained according to the logic of capitalism as a social and economic system. Rather, Carlotto's noir universe is chaotic and unpredictable and his characters do not understand themselves or their actions beyond a basic inclination towards financial gain and self-interest. As such, I argue that affect understood as an autonomic or bodily response to one's environment better explains Carlotto's noir world; and that 'noir affect' - which takes and inverts the positive potential of affect identified by Massumi and others - acts on populations to negatively imbricate or subsume action and character in the unruly violence of the 'free' market.
\end{abstract}

Bio:

Andrew Pepper is Senior Lecturer in English at Queen's University Belfast. He is the author of Unwilling Executioner: Crime Fiction and the State (OUP 2016) and The Contemporary American Crime Novel: Race, Ethnicity, Gender, Class (EUP 2000) and the co-editor of Globalization and the State in Contemporary American Crime Fiction (Palgrave 2016). He is also one of the co-editors of the forthcoming Routledge Companion to Crime Fiction. He has written a series of crime novels set in nineteenth-century Britain and Ireland including The Last Days of Newgate (2006) and Bloody Winter (2011), all published by Weidenfeld \& Nicolson. 
There are two related starting points for this essay on the noir worlds of the Italian novelist Massimo Carlotto. The first is the more straightforward, given Carlotto's situatedness in his home Italian culture, notably the Veneto or the Nordest, which is also the title of one of his novels. Noir, in Carlotto’s capable hands, owes a significant debt to its US forbearers (the English translation of Nordest, Carlotto’s 2009 novel, is Poisonville, a direct reference to the town in Hammett's 1929 novel Red Harvest). But it is also implicated in a set of transnational networks extending out from the Veneto and Italy to the world. Following the current move to consider the global spread of noir beyond its foundational spatio-temporal moorings, ${ }^{1}$ this essay posits Carlotto as one of the key practioners of "neoliberal” or “capitalist” noir ${ }^{2}$ - but without arguing for neoliberalism or capitalism in its neoliberal phase as totalizing systems which structure and determine all modes of existence and potentialities of life. The second related jumping off point is more complicated and requires careful unpacking but for the purposes of summary, it can be explained through a simple paradox of contemporary existence: how life, on the one hand, necessarily exceeds attempts to order and control it and how, on the other, life becomes the target for increasingly far-reaching techniques of power.

The noir universe can in part be explained by or subsumed into the first element of this paradox: life in a Carlotto novel is typically violent, chaotic, unpredictable and indeterminate. People kill and are killed because Carlotto's universe is a violent, competitive one, but often his characters have no direct insight into their actions and motivations. In this sense, as this book as a whole and my essay want to demonstrate, there is a clear and compelling link between "noir" - however it is defined - and "affect" which "refers generally to bodily capacities to affect and be affected” and is typically understood as an autonomic or human bodily response to one's environment “in excess of conscious states of perception". ${ }^{3}$ As such affect is both pre-conscious and pre-individual, a state where 
intentionality or causality is harder to map. As Patricia Ticineto Clough puts it, without exactly clarifying matters: "it refers to indeterminacy, metastabilty, where the unstable preindividual forces... are neither in a linear nor deterministic relationship to the individuated molar body which these pre-individual forces nonetheless constitute." ${ }^{4}$ If this sounds a lot like Carlotto’s noir universe, defined by unpredictability and indeterminacy, and where this generalized sense of unpredictability and indeterminacy acts not on individuals but on worlds (what we might call "affective atmospheres”), this still requires us to think about the knotty problem of causality or intentionality. By this, I am referring not simply to the issue of whether or how far noir fiction disrupts the conventional linearity of other forms of crime fiction or indeed whether noir characters understand their own acts as intentional but rather the larger question of how we might conceive of the relationship between affect as "nonconscious” and “non-signifying” and capitalism as an essentially determining and deterministic system; that is, the "affective atmosphere” of capitalism.

One of the shortcomings of my own account of Carlotto's work in Unwilling Executioner: Crime Fiction and the State (2016) is its willingness to use an unproblematized Marxian frame to account for the conjoined nature of the legal and illegal worlds and for the effects of a capitalist mode of production on the actions and moral capacities of Carlotto’s characters. ${ }^{5}$ Whether intended or not, the result is, in effect, a recalibrated ideological critique whereby Carlotto’s novels, notably Arrividerci amore, ciao (2000), translated from the Italian by Lawrence Venuti as The Goodbye Kiss (2006), critically interrogate - and even demystify - the devastating consequences of a generalized "logic of accumulation” and of "the unstoppable march of capitalism in its neoliberal phase.”6 Such an account might capture the extent to which capitalist forms are gradually and increasingly imposed on noncapitalist spheres but it misses the particular ways in which affect enters noir, or is alwaysalready present within noir, as a non-signifying bodily feeling outside of its objectification or 
object-targeting by power. If we see noir as a kind of unruly counter-narrative to what Lauren Berlant calls the "good-life fantasies" (which are, in turn, central to her account of “cruel optimism”), then affect, like noir, “enters the description of the dissolution of the good-life fantasies not as a symptom of any mode of production or ideology’s damaging imprint”. Rather, “[its] strength as a site of potential elucidation comes from the ways it registers the conditions of life that move across persons and worlds". ${ }^{7}$ Still, for my purposes, this last and perhaps overly general reference to the "conditions of life" does not quite get to grips with the particularities of power as it envisaged by Carlotto - and it is therefore to the late work of Michel Foucault and its application by Ben Anderson that we need to turn to, in order to fully comprehend the paradoxical move in Carlotto, whereby his protagonists simultaneously exceed attempts to order them and yet become targets for new techniques of power.

Foucault's The Birth of Biopolitics (2008) traces the emergence of biopolitics as way of managing and governing populations (or securing order through self-government or governmentality) in the context of the consolidation of capitalism. As Anderson explains, “Foucault's initial diagnosis of the emergence of forms of power that are 'bent on generating forces, making them grow, and ordering them'... was tied to a unique set of politicaleconomic transformations, specifically the need for an expansion of the productive forces in capitalism”. ${ }^{8}$ Anderson finds a way of connecting “a specific economic ordering” - whereby “capitalist forms” are “imposed on a pre-existing, non-capitalist sphere”, “value-creation becomes indistinct from social activity”, and "surplus value is extracted throughout all of life" ${ }^{\text {- }}$ - to a more general ordering of life (or the "strategic coordination of the multiplicity of forces that make up life”). Crucially, for his and indeed for my purposes, what "links this ordering of capital/life relations with a logic of governing is a problematisation of life as contingent, as tensed between chaos and determination (as expressed through terms such as 
uncertainty, indeterminacy, discontinuity and turbulence)." ${ }^{10}$ In other words, exactly those affects which characterize Carlotto's noir universe. Rather than limiting this universe to a consequence of economic determinism or indeed downplaying the effects of competition, accumulation by dispossession and the organization of life around the market, Carlotto’s emphasis on both, by drawing attention to the violent, unruly contingencies and uncertainties that affect his characters, allows us to fully see the ways in which "affective life is imbricated in the working out of the neoliberal problem of how to organise life according to the market."11

In this essay, by focusing on two novels featuring criminal-turned-restaurateur Giorgio Pellegrini - The Goodbye Kiss and Alla fine di un giorno noioso (2011), translated by Antony Shugaar as At the End of a Dull Day (2013) - and a "standalone" novel about the failures of the justice system called L'oscura immensità della morte (2004), translated by Lawrence Venuti as Death’s Dark Abyss (2006), I want to reconfigure Anderson’s formulation (e.g. "the working out of the neoliberal problem of how to organise life according to the market”) in more straightforward terms as a problem of action. In Carlotto's noir worlds, taking bold and decisive action, which is the hallmark of his protagonists, is neither the unproblematic working out of individual agency in the face of new techniques of power nor a symptom of the subsumption of life by and into the market (whereby characters become unthinking and uncritical embodiments of, say, accumulation or competition). But this, I think, is where certain theories of affect, whereby the emphasis is also placed, as Anderson puts it, on "how affective life exceeds attempts to make it into an objective-target for forms of power,"12 diverge from what we are calling "noir affect”: to quote Breu and Hatmaker in their introduction, “a name for specific kinds of affect (loss, sadness, rage, guilt, shame, resentment, humiliation and refusal) and the name of a specific practice of narrative to dramatize such affects”. ${ }^{13}$ In other words, what Brian Massumi calls the hopeful 
dimension of affect whereby the uncertainty produced by complex organizational structures allow a "margin of manoeuvrability”14 or Antonio Negri calls "biopower from below” (i.e. “affective life is the non-representational 'outside’ that opens up the chance of something new”15) is recast into its noir equivalent: action that is neither "becoming” nor subsumption by or into power but something darker, more agonistic, more inchoate. In the rest of this essay, which is divided into three sections - noir affect and good-life fantasies, creative capitalism, and justice and violence - I will explore how Carlotto, across three exemplary novels, takes the possibilities inherent in these more hopeful accounts of affect (where bodies act as well as being acted upon) and recasts them into their noir equivalents (whereby the working out of the neoliberal problem of how to organize life according to market principles produces its own "noir affects": rage, anxiety, shame, and humiliation). At stake here is not the question of how the resulting narratives function as critiques (of new forms of power) or are complicit with these new forms of power, but rather how or how far they are able to make connections between the violence which inevitably results from these noir affects and modes of accumulation, securitization (or objective-targeting) and value-creation that are ostensibly treated as "normal” and what the implication of these connections might be.

\section{Noir Affect and Good-Life Fantasies: The Goodbye Kiss}

In her book Cruel Optimism (2012), Lauren Berlant casts “that moral-intimateeconomic thing called the good life” or people’s attachment to “conventional good-life fantasies” (e.g. enduring families and coupledom, stable, well-paid jobs, leisure time, economic opportunity, public justice) as something that paradoxically acts as obstacle to one’s flourishing (i.e. when an object or scene "that ignites a sense of possibility actually 
makes it impossible to attain the expansive transformation for which a person or a people risks striving”). ${ }^{16}$ As Breu and Hatmaker explain, cruel optimism is “a neoliberal affective state” whereby “discourses like self-help, postmodern management, and 'staying positive’ function to cover over the exploited subject's anxious relationship to a neoliberal order that is systematically impoverishing her." ${ }^{17}$ For Berlant, the contemporary "dissolution of optimistic objects/scenarios that once held the space open for the good-life fantasy" has in turn produced new forms - new "dramas of adjustment” - which are better able to trace the correlative anxieties of economic precariousness and affective distress. ${ }^{18}$ But The Goodbye Kiss is not one of these new dramas, nor can it be, because rather than a "positive affect" that becomes “a negative phenomenon,” Carlotto’s noir begins with the assumption that affects are negative and life is unpredictable, dangerous and anxious - and proceeds to show us how the attendant violence is intimately connected to the conditions of precariousness that result from the neoliberal subsumption of life by the market. The extent to which this puts pressure on Berlant's claims about the particular forms that cultural fantasies of affective distress caused by neoliberal precarity can take, and whether any kind of "affective solidarity” is possible, constitutes one of this essay's key lines of inquiry.

To claim that The Goodbye Kiss doesn't operate, on one level, as a cultural fantasy about "the good life" would be misleading. The first half of the novel traces the rise from petty and not-so petty criminality to ostensible respectability and the "good life" of Giorgio Pellegrini who moves seamlessly and without any kind of perturbation from adventurer and proto-revolutionary to aspiring capitalist. In doing so Carlotto gives us an early hint that violent competition should be understood as the measure of all life. In one sense, there is nothing especially atypical about this: crime stories have long since been motivated the acquisitive ambitions of their protagonists and Carlotto’s noir is no different. Having seen the wealth casually displayed on the Milanese streets - "I'd go to the centro and spend hours 
eyeing the people and cars. A tone of cash was floating around, and mostly everyone was oozing confidence"19 - Pellegrini is made aware of his lowly status ("I was a marginal, an outcast...a bum”) and what he needs in order to climb the social ladder and realize the good life: 'Money. I needed money to lift myself from the dung heap I was stuck in. Then I’d establish a respectable position and stroll through the centro...flaunting the worry-free face of winner” (29). Crime, and as the story progresses increasingly violent crime, resulting in multiple deaths, imbued by the spirit of accumulation by dispossession and acquisitive competition, becomes the proverbial conveyer belt to wealth and respectability: once he has acquired a sufficient sum, Pellegrini is literally able to purchase his "rehabilitation” with the help of a Veneto lawyer and political fixer, though the lawyer, Sante Brianese, is quick to emphasise the performativity of respectability over the conspicuousness of consumption. “Around here it isn’t important to know where the money originates...But it mustn't stink of wrong-doing. On the contrary, it should carry the fragrance of hard work and a creative intellect” (100).

Where The Goodbye Kiss does its important political work is in its revelation of what Pellegrini finds once he enters respectable Veneto society ("the hunger for money was the same everywhere” 98) and opens a restaurant, La Nena, frequented by the city’s great and good. Not only is nothing at all different - as Carlotto tells us, "the legal and illegal economies were merged in a single system, offering the opportunity to grow rich and build a discreet position of power...Business, crime and politics” (108). More to the point, the legal economy works in exactly the same and according to the same logics as the illegal one: so that the “skills” Pellegrini has learnt running a brothel or setting up an armoured car robbery (logistics and planning, keeping costs down, exploiting staff, and being prepared to act decisively and with force if necessary) are the same ones he uses to run his restaurant and help out his new friends. "You're role is to protect our group of friends," [Brianese] once 
told me. "To restore legality. Ours, of course” (113). The idea that the legal world is every bit as competitive and cutthroat as the illegal world is not a new one, of course, but what Carlotto does so well, and what noir is able to show us so clearly, is that the good-life fantasies that drive the pursuit of crime in the first place are themselves imbricated in the networks of control and objective-targeting that reinforce neoliberalism's reordering of the social as well as economic domains. This may be akin to Berlant's "cruel optimism” insofar as the affective yearning (which is one sense positive) has negative consequences but Carlotto’s "noir affect” takes and extends this formulation so that the desired-for (e.g. positive) good-life fantasy is stripped bare and violated to such an extent that its value as a goal or target is fatally undermined. Even the fantasy is baseless - subject, as it is, to the imperatives of accumulation by dispossession and violent competition.

In order to further his “rehabilitation” case, and to underscore his claims to respectability, Pellegrini marries Roberta after a whirlwind courtship in which Pellegrini traps her using the carefully calibrated language and actions of the good-life fantasy:

I acted as if I understood and tried to reassure her with banal speeches about the sincerity of my feelings. Finally I sent her a clear message, revealing my dreams and my plans to her. She seemed the image of my ideal woman. I escorted her to the door of her building, saying goodbye with a chaste kiss on the cheek (118). Pellegrini may try - half-heartedly - to convince himself that he "loved her company" and she "filled a hole in my life" despite the fact he "really didn’t know what to do with a woman who had no intention of giving me head or letting me fuck her in the ass” (119). But his pursuit of and marriage to her is part of the logic of acquisition whereby she, like the restaurant and other trappings or commodities of the good life, can be purchased and traded and where the fantasy is explicitly treated as fantasy - and as a game whose end goal is only ever Pellegrini’s self-advancement: “To crown her soap-opera dreams, I took her to 
Venezia...A great restaurant, a turn in the gondola, a serenade. In Piazza San Marco, I put a little box in her hand” (119). In Carlotto’s noir universe, it isn’t the case of Pellegrini’s past returning to haunt him, though this would be one way of reading the turn of event: Roberta interrupts Pellegrini meeting with a dirty cop from his former life and when the cop is murdered (by Pellegrini of course) and the murder publicized, Roberta draws the appropriate conclusions and therefore puts herself in the crosshairs. Since there is no distinction between legal and illegal domains and therefore between Pellegrini's past and present, this is Berlant's good-life fantasy reconstituted as noir affect. There is no affective masking and no affirmative shadow lurking behind the negation: rather what we see is the "affective environment” of neoliberal capitalism turned inside-out in order to underline all that is specious, false, exploitative, violent and horrific about a logic and a moment where there is nothing (even or especially love) outside the market. In a deliriously noir inversion of romantic coupling, Pellegrini slips aspirin into his wife's food, knowing she is allergic and that the allergic reaction will kill her, and he even tells her this - "I put crushed aspirins in all the food you've eaten in the last twenty-four hours” (139) - while he watches her lose consciousness and die before the ambulance he's called arrives. The novel concludes not with Pellegrini anxiously waiting to see whether he has evaded justice but rather with his successful rehabilitation at which point the noir-happy ending can take place. "I burst into tears. Of happiness. I'd done it. The nightmare was over. I could finally be like everybody else” (144). The irony of course is that insofar as "affective atmospheres” are shared rather than solitary - because affect acts not just upon individual bodies but also worlds - he is not not like everyone else which is another way of saying that everyone else is just like him. Not everyone, perhaps, would be capable of such grotesque cruelty but this is what happens when affect and affective life enters a noir universe that is itself "imbricated in the working out of the neoliberal problem of how to organise life according to the market.”20 


\section{Creative Capitalism and Violence: At the End of a Dull Day}

Carlotto’s sequel to The Goodbye Kiss, At the End of the Dull Day, picks up Pellegrini’s story a year later, once he has been fully assimilated into the Veneto’s “respectable” social and business worlds. In doing so, it seeks, ostensibly at least, to reverse the narrative trajectory of the earlier novel (from criminality to "respectability") by moving Pellegrini in the opposite direction: hence, when he is swindled by his lawyer and former friend, Sante Brianese, Pellegrini sets out to show his newfound acquaintances who is "really" is and what he is capable of:

They'd all known a different man, a man who was willing to do anything to please people and to be accepted. None of them had even the slightest idea of who Giorgio Pellegrini really was. ${ }^{21}$

Of course this is something of a misnomer or a misrepresentation, given that many of these same acquaintances have directly benefitted from the violence Pellegrini has dished out in their favour. But it speaks to or about the ways in which capitalism as a system typically obscures its predations and exploitative tendencies through claims to moral probity. ${ }^{22}$ The noir un-masking of these same tendencies in Carlotto's sequel is foregrounded from the outset: hence we see how Pellegrini’s social ascension (“I was now 'one of them.' And not just any one of them. I was a winner” 24) is founded upon his violent exploitation of the foreign prostitutes he “works” as their pimp. Just as David Harvey urges us not to distinguish between “extra-legal activities, such as robbery...predation, violence and coercion” and the accumulation of wealth "by legally sanctioned exchanges under conditions of non-coercive trade in freely functioning markets” (insofar as the capital has always “exhibited immense flexibility in its capacity to appropriate the common wealth”23), Carlotto wants us to see Pellegrini’s activities not merely as criminal and predatory but also as 
constitutive of capitalism's capacity to smoothly appropriate or accumulate via dispossessing others of their labour and hence their wealth. The threat to the women may be physical “we made sure they couldn’t miss a pair of brass knuckles apparently left in plain view” (21) - but in other ways the intent is to treat the women in such a way that they don't notice what is being done to them until it is time to dispose of them: "We sent them to live in comfortable, spacious homes, where Nicoletta [his partner] took personal charge of them. She taught them everything they needed to know about clothing makeup, perfume and etiquette” (21). In other words, they are well treated not out of any benevolent intent demonstrated by Pellegrini and his partner but because it is in their commercial interest to do so. That exploitation girds and supersedes this benevolence is evidenced by the "knuckles" and manner in which the women are sold - like cattle - and shipped off to North Africa once their economic usefulness has been expended.

All of this requires careful elucidation about the precise nature of the relationship between noir and capitalism and between what we are calling noir affect and capitalism as “affective atmosphere”. In one respect, as I have argued elsewhere, it is not entirely wrong to propose Pellegrini and his violence as symptom of the worst tendencies of accumulation (by dispossession), acquisition and competition. ${ }^{24}$ But it is the determining aspect of this relationship that is troubling, not least in light of work carried out by Berlant and others on affect that does not want to and indeed cannot treat a subject's affective life as "symptom of any mode of production's or ideology's damaging imprint”. ${ }^{25}$ At stake is the question of how to treat noir as an affective atmosphere and how to calibrate it to the obvious Marxian overtones of Carlotto's novel (i.e. whereby he is explicitly commenting on the exploitative practices of capitalism). Part of the problem for any account that might want to reduce Pellegrini to the sum of the forces acting upon him is that he doesn't, in Carlotto's own terms, cohere as a subject, even a determined one. For one thing he is too unstable, too 
impulsive, despite his mendacious claim early in the novel that he had been able to lay "to rest those impulses I'd been unable to control in the past" and that "I no longer needed to get drunk on violence and cruelty in order to feel I was alive” (28). Instead, the novel is fundamentally “about” Pellegrini’s tortuous efforts to control these impulses (in effect to "know himself”) and his inability to do so. More to the point, Carlotto wants us to understand that these efforts make no sense, rationally speaking, and are founded on the same exploitative practices as his business activities. Take, for example, his insistence upon watching his wife, Martina, both smear creams and ointments onto her face and body and pedal furiously on an exercise bike - ostensible to help her ward off "the aging process and keeping body and mind in tip-top shape” (33). In actuality, this is a misogynistic power-play that stands in lieu of "the intoxicating thrill of inflicting pain on others" (46) and in doing so exposes (once again) the falsity of good-life fantasies.

The broader point is that Pellegrini has little or no insight into who or what he is beyond an instinctive understanding of where his own violence might lead - and an implicit realization that he possesses little or no ability to control these tendencies. As he tells Brianese:

I must just be one of those unpredictable variables in your fucked-up system, Counselor, and I can promise you that I've shown considerable restraint and offered no more than a tiny demonstration of the extent of my professional skills in the field of inflicting violence (60).

Rather than exhibiting the same capacities, and the same logic, then, as the system of graft and corruption that Brianese presides over (e.g. "The toxic leachings from a dump into the open sea...bribes paid to tamper with the health department statistics” 61), Pellegrini represents something "unpredictable” and even outré to this system. To understand what this might mean we need to return to theories of affect, and more particularly of noir affect, 
because these too underscore the ways in which affects are "non-intentional, bodily reactions”26 that align subjects for and against prevailing systems of power. This understanding of affect, derived initially from Spinoza, as "the power to affect and be affected”, is interpreted optimistically by Brian Massumi insofar as it has positive political implications regarding our abilities to engage with the world and each other in potentially transformative ways: "To affect and be affected is to be open to the world, to be active in it and to be patient for its return activity. This openness is always taken as primary. It is the cutting edge of transformation.,"27 Massumi's interventions have opened up space for theorists like Antonio Negri to think about affect as "biopower from below" - summarized by Anderson as follows: "how affective life exceeds attempts to make it into an object-target for forms of power." 28 This is all well and good but noir is a contrary "heretical" genre, if indeed it is a genre, ${ }^{29}$ and certainly one that is genetically disinclined to speak in optimistic ways about positive transformations of any kind. So the question remains: how is it possible for noir to avoid the trap of treating all human activity and emotion as trapped and determined (because affect, unlike emotion, is “a nonsignifying, nonconscious 'intensity' disconnected from subjective, signifying, functional-meaning axis to which more familiar categories of emotion belong"30) while at the same time thematizing the intensity and unpredictability of affective life in ways that negate rather than validate its "potentially emancipatory qualities"31 (because "noir affect" is first and foremost a negation)? And how do all of this while still finding ways to critically interrogating the violent precariousness of life - affective or otherwise - as it is lived under neoliberalism?

In this section, I have tried to show how I think Carlotto's At the End of a Dull Day pulls off the first part of this formulation - drawing suggestive links between crime and capitalism and between Pellegrini's acquisitiveness and violent competitiveness and the everyday logic of business while emphasising his unpredictability and unknowability even to 
himself. In the remaining part of this section, I'd like to try and develop this last claim - to show how Pellegrini’s unpredictability does not validate affective life’s “potentially emancipatory qualities” but rather is explained by the creative destruction and violence characteristic of what we might call capitalism in its neoliberal phase or moment. ${ }^{32}$ After Pellegrini has been swindled by Brianese, his lawyer and a rising political star, he turns on his former mentor and subjects Brianese's wife to a horrific beating during what is intended to look to the world at large as a botched robbery (but where he reveals the truth to Brianese - to "persuade” the lawyer to pay back what he has stolen). By way of retribution, Brianese sets the Calabrian mafia, 'Ndrangheta, onto Pellegrini and his restaurant so that, initially, he has no choice but to let them use it as "washing machine" to launder their dirty money (94). Therefore rather than treat the “famous 'locomotive'...the legal and illegal economies merged in a single system"33 as a monolith, Carlotto sets the "big beasts” of the conjoined domains of politics (Brianese as "lawyer and...parliamentarian of the Italian republic” 15) and organized crime (as represented by the various figures of 'Ndrangheta including the local boss, Giuseppe Palamara) against Pellegrini who positions himself not as social bandit but rather as a new or “creative” economy entrepreneur selling his human capital in order to earn his freedom. ${ }^{34}$ Indeed this is the precisely the language Pellegrini uses to frame his struggle with Brianese and especially the Calabrian mafia, which he portrays as the "crime" equivalent of General Motors or IBM, hierarchy-bound, procedure-heavy behemoths, to his nimble, creatively-inflected “start-up”. His “creative criminality” venture, then, draws from the "astounding wave of creativity in every field, from music and film and art to crime" in an earlier epoch (the Situationists?) and is set against not just "the dull, repetitive crimes committed by the capitalist establishment” but also by the various "international Mafias” that "moved in" aided by "globalization" and the decimation of "free market competition" so that “the spheres of illegal pursuits turned grey and humdrum like everything else” (122). 
There is of course something self-serving on Pellegrini’s part in comparing “People like the Palamaras” to “dinosaurs who'd always lived in a culture devoid of imagination” and his own Marcuse-inspired “creative crime” venture premised on "Confusion. Chaos. Breakdown. Hurly-burly” that would "Blind them with imagination” (122-4). Yet it is true that his plan to bamboozle Palamara and his henchmen by robbing a consignment of still-tobe-laundered money and cover his tracks with a series of elaborate stunts and carefully planned alibis ultimately succeeds in masking his culpability and his threat to Brianese’s position is such that the lawyer-cum-politician agrees to pay back what he has stolen. Reflecting on where this leaves him, Pellegrini imagines his future criminal activities as a development of his creative endeavours ("I would no longer get bogged down in activities like the prostitution ring, which demanded a special dedicated logistical structure and organization” 182). But insofar as he claims that "[f]lexibilty would be the order of the creative local economy” it is striking how closely success here evokes, deliberately I think, the ways in which "neoliberalising processes attempt to harness the creative, inventive dimensions of life.”35 So where does this leave us? Should we see Pellegrini’s exploits as success? Is this how Carlotto wants us to understand his protagonist's “creative criminality”?

For a start, Pellegrini is only able to broker a deal to ensure his survival (and hence success) once he has earned the backing of an elite member of the Veneto business establishment and only on the grounds that the status quo prevails. The situation, this nameless figure, explains may be "fluid" in the country at large "but there will never be any real change in the Veneto” (176). Then we need to think about how far the violent, brutalizing logic that informs Pellegrini’s victory ("I was born to ass-fuck my fellow man and it was something I really enjoyed. It made me feel alive” 179-180) can be seen as endorsing neoliberalism’s harnessing of creativity for its own ends. "You're a monster," Brianese tells Pellegrini, a taint that requires careful consideration in light of the lawyer's 
accomplishments in the field of graft, violence and corruption (159). But is Pellegrini a monster and if so what informs or explains this monstrosity? Neoliberalism, like capitalism previously (to which of course neoliberalism is yoked) cannot be wheeled on as unproblematic explanation but Breu and Hatmaker are surely correct in their assertion that the resurgence of noir proper in neoliberal noir...is organized around a new, present form of negativity, one that challenges the affirmative moral and commodified rhetoric of self-invention, self-investment, and self-maintenance as well as deserving winners and losers that is central to contemporary neoliberalism. ${ }^{36}$

Perhaps the only qualification I would want to make is to think about how ambiguity enters into and unsettles any straightforward affirmation/negation formulation. As such, Pellegrini's creative criminality, informed by attendant techniques of privatization and responsibilization, is perhaps best understood as affirmation and negation: a manoeuvre that draws from while at the same time challenges the affirmative logic of neoliberalism that proposes unproblematic freedom as an end-result. What we find in At the End of a Dull Day is agonistic ambivalence: a central character who is both monster and successful entrepreneur, and violence that sets Pellegrini free and at the same time binds him into new and ever-proliferating forms of power. If this leaves open the question of how we as readers identify or not with Pellegrini's cunning and monstrousness then I will try to address this issue in the final section.

\section{Noir Justice as Abyssal Violence: Death's Dark Abyss}

Death's Dark Abyss is perhaps the bleakest of all of Carlotto's novels because it takes a figure who should, unequivocally, command our sympathies as readers - far more so than the pathologically self-interested Pellegrini - and turns him into "a dangerous lunatic". ${ }^{37}$ If 
Silvio Contin once enjoyed what we might call a good life rather than merely hankering after a good-life fantasy - "I was a sales agent for top-drawer wines. I had a secretary and tooled around in a Mercedes. I had a wife and son. Friends and relatives. Clara was a beautiful woman” (19) - all of this is destroyed when his wife and son are killed in a botched robbery. In the present of the novel, Contin is living a hollow, diminished life mending shoes for a living and eating dinners in front of the TV when he is asked to show clemency to one of the robbers, Raffaello Beggiato, who was sentenced for thirty years but who has contracted cancer and is looking for a conditional release in order not to die in prison. His response is initially bodily, instinctive, rather than rational or conditioned by "feelings": "The pain throbbed more intensely, and a twinge rose from his stomach to my throat...That miserable fuck thought I was capable of noble gestures. To forgive you need to have feelings, a life” (19). Here, then, feelings or emotions are not, in any straightforward sense, synonymous with pre-social, pre-individual "intensities" that we might associate with affect. If "feelings" for Contin are connected to the life he once enjoyed, what he "feels" in the present is more akin to what we are calling "noir affect”: those darker intensities that he doesn't understand and can’t fully control. Carlotto characterizes these intensities not as rational - “I didn’t possess the tools to confront death rationally" Contin admits, and then ruminates on "the loss that sometimes kept me from thinking rationally” (23) - but rather as an abyssal sentiment that drives Contin to violently debase himself and others in pursuit of what he believes is justice.

As with Pellegrini, then, there is much to contemplate in relation to Contin's intent and how far he acts, i.e. how successful he is at exceeding or evading attempts to control or order his existence, and/or is acted upon: i.e. how far he is subject to the regulatory tug of power, whether associated with the state or more generally with a biopolitical management of populations. For his part, Contin believes, as much as he is capable of such thinking, that 
his actions in the present, premised as they are on denying Beggiato the opportunity to enjoy the fruits of his ill-gotten gains and uncovering the identity of Beggiato’s accomplice who was never punished for the double murder, are premised on redress, if not exactly justice: so that when he finally locates the accomplice, he muses, "Before sending him to prison for the remainder of his life, I had the chance to make him understand the meaning of pain, anguish, loss” (70). Contin may be capable of rational action and intent on one level, then, insofar as the clemency he ostensibly shows to Beggiato by not opposing his bail is a calculated ruse so he can follow Beggiato, once he has been released, back to his accomplice. But in other ways the fuel that motors his "murky plan” (48) is "[a]nxiety and pain” and a "howl that was difficult to repress" and that "ripped open my mind with its obsessive rhythm and plummeted straight to my chest" (51). In other words, this is what we are calling "noir affect” as embodied state: those negative registers of loss, rage, anxiety and humiliation which act on the body's central nervous system in order to produce certain behaviours that are of the opposite or negation of responsibilization and justice. So it is that Contin decides not to "run to the police" (62) but follows his "instinct" (65) which equates in his own mind to “death’s dark abyss" and that perhaps explains his decision to kill the accomplice and his wife with an axe. I say "perhaps explains" because while the act is premeditated insofar as Contin first lays out plastic sheeting to cover up the crime, it also seems to come out of nowhere ${ }^{38}$ : "From the bag I grabbed an axe handle and hit her in the knees. She fell to the floor, and I kept swinging till she passed out” (101).

The bigger question, for me, is how to make sense of Contin's hate and the other negative or noir affects that “explain” his actions. One way would be to treat Contin’s aberrance and eventually his violence as the product of what has been done to him individually and/or his own pathologized deviance (i.e. what he has done is explained by who he is). But if we are to identify the manifestations of "noir affects" in what he does and 
who he is, we also need to remember that "affective atmospheres are shared, not solitary, and that bodies are continuously busy judging their environments and responding to the atmospheres in which they find themselves." ${ }^{39}$ For Sara Ahmed, meanwhile, affects are akin to emotions like hate which "do things": i.e. in "affective economies" they "align individuals with communities - or bodily space with social space - through the very intensity of their attachments." ${ }^{40}$ Which begs the question: how might we begin to understand the affective atmosphere or affective economy of Carlotto’s novel? And how is Contin’s bodily space connected to the larger social space through the intensity of his hate? Here the novel's indictment of the Italian justice system and the failure of the state to adequately balance the protection and justice owed to victims with the human rights of perpetrators is brought into stark relief but it is only when we think about Contin's animal cunning in relation to his condemnation of state praxis that the novel's larger concerns begin to make sense. As Anderson puts it, 'not only is affective life always-already organised into collective affects such as state phobias but also neoliberal processes attempt to harness the creative, inventive dimensions of life." ${ }^{41}$ In the case of Carlotto's noir-worlds it is just that affective life and affective atmospheres are premised upon negation - whereby Contin’s rage and anxiety is aligned with the social space he belongs to (e.g. state failure and neoliberal capitalism) - and where the "creative, inventive dimensions of life” are enacted through an instinctive urge towards destruction and violence.

\section{Conclusion: Noir Affect as Political Unmasking?}

In her book Cruel Optimism, Lauren Berlant contemplates the political implications of focusing on affect rather than ideology and seeks a way around Slavoj Žižek’s suspicion that "a politics of affect is an oxymoron or worse, a bourgeois mode of sensational self- 
involvement masquerading as a radically ungovernable activity of being”. As such, she asks whether "to talk about the activity of affect...in political terms is mainly to be mired narcissistically...or passively in the present?”42 To turn this formulation around for a moment, we might ask how successfully an ideological critique would be able to make sense of activity or behaviour that is not first and foremost to be understood as the direct consequence or symptom of the means of production, either where the primacy of capitalism as a mode of economic and social organisation is reinscribed or questioned. Is it possible to understand all of Giorgio Pellegrini’s actions, even ones that don’t make full sense to himself (e.g. watching his wife "spin” on her exercise bike and rub creams into her body), or Silvio Contin's seemingly bottomless rage as being determined by the means of production? Can we easily see these novels as ideological unmaskings and if so what ideologies precisely are being unmasked? Pellegrini, after all, would seem to be fully supportive of or beholden to the transformations ushered in by neoliberal rhetoric about creativity, responsibilization and self-maximization. But nor, self-evidently, are these novels endorsements of new techniques of power and modes of behaviour: Carlotto’s politics - as evidenced in his claims about Mediterranean noir (e.g. "to tell stories with a wide swath; to recount great transformations; to denounce but at the same time to propose a culture of solidarity as an alternative”43) - are leftist and clearly we are meant to see some kind of connection between Pellegrini's murderous inclinations, his acquisitive tendencies and his competitive ruthlessness and the wider logic of capital.

These are not obviously protest novels, then, where the conditions that force characters to act in particular ways are decried - Pellegrini acts with too much glee and a not-insignificant amount of self-insight for The Goodbye Kiss or At the End of a Dull Day to be outraged at the state of the world. This is where the framing of his actions, and those of Silvio Contin, and Carlotto's noir-worlds, in terms of affect is so instructive: because what it 
allows us to do is to posit individual behaviour as singular, complex, ambiguous, messy and unruly (all of these descriptors would seem to apply to Pellegrini and Contin) while at the same time seeking to locate this behaviour not as a direct product of what Berlant calls "the heuristic 'neoliberalism”” as “a world-homogenzing system” or the affect “of powerful, impersonal forces” but rather as acknowledgement that bodies and environments are constantly acting and acting on one another: that "affective atmospheres are shared...and...bodies are continuously judging their environments and responding to the atmospheres in which they find themselves." ${ }^{44}$ For Berlant, the political work of such texts is done in their descriptions of dissolutions of good-life fantasies not as symptom of ideology but in terms of the way they register "the conditions of life that move across persons and worlds, play out in lived time, and energise attachments." ${ }^{45}$ But what of the noir aspect of “noir affect”? As this essay has demonstrated, noir in general and Carlotto’s novels in particular are highly skilled at forensically dissecting "good-life fantasies” but they are less inclined that Berlant would like to show us how positive attachments are played out in lived time. Noir, after all, is first and foremost negation. That said, noir does not reduce human behaviour to rage, hate and violence; unease, ambiguity and anxiety can and do flourish just as well in noir texts. Therefore the political work Carlotto's novels perform is, in part, at the level of "moral rebellion” on the part of readers (who see what or who Pellegrini is and strive to live different lives) ${ }^{46}$ but this work also occurs in the glimpses we have of ourselves in Pellegrini and Contin (their frustrations and their capacities for action) and our careful delineations of what these identifications mean in terms of our own complicities with the same systems and world we have to negotiate on a daily basis. 


\section{NOTES}

${ }^{1}$ See, for example, Justus Nieland and Jennifer Fay, Film Noir: Hard-Boiled Modernity and the Cultures of Globalization (New York: Routledge, 2009).

2 "Neoliberal noir" is best delineated by Christopher Breu, "Work and Death in the Global City: Natsuo Kirino’s Out as Neoliberal Noir” in Andrew Pepper and David Schmid (eds.)

Globalization and the State in Contemporary Crime Fiction (Palgrave Macmillan: London, 2016), 39-57. "Capitalist noir" is outlined by Pepper, Unwilling Executioner: Crime Fiction and the State (Oxford University Press, 2016), 228-238. The relationship between "neoliberal”, "capitalist” and affective noir will be elucidated in this essay.

${ }^{3}$ See Patricia Ticineto Clough, "Introduction" in Clough and Jean Halley (ed.) The Affective Turn: Theorizing the Social (Durham and London: Duke University Press, 2007), 2; Patricia Ticineto Clough, "The New Empiricism: Affect and Sociological Method”, European Journal of Social Theory 12:1 (2009), 43-61; 48.

${ }^{4}$ Clough, “The New Empiricism”, 48.

${ }^{5}$ Pepper, Unwilling, 235-238.

${ }^{6}$ Pepper, Unwilling, 236.

${ }^{7}$ Lauren Berlant, Cruel Optimism (Durham and London: Duke University Press), 15-16.

${ }^{8}$ Ben Anderson, “Affect and biopower: towards a politics of life”, Transactions of the Institute of Geographers, 37 (2012), 28-43, 29.

${ }^{9}$ Anderson, "Affect”, 33

${ }^{10}$ Anderson, "Affect”, 29.

${ }^{11}$ Anderson, "Affect”, 40.

${ }^{12}$ Anderson, "Affect”, 34.

${ }^{13}$ Christopher Breu and Elizabeth Hatmaker, "Dark Passages: Noir as Affect”.

${ }^{14}$ Brian Massumi, Parables for the Virtual: Movement, Affect, Sensation (Durham and London: Duke University Press, 2002), 3.

${ }^{15}$ See Anderson, “Affect”, 34.

${ }^{16}$ Berlant, Cruel, 2.

${ }^{17}$ Breu and Hatmaker, "Dark Passages".

${ }^{18}$ Berlant, Cruel, 3.

${ }^{19}$ Massimo Carlotto, The Goodbye Kiss, trans. Lawrence Venuti (New York: Europa, 2006), 28. All subsequent citations refer to this edition.

${ }^{20}$ Anderson, "Affect”, 40.

${ }^{21}$ Massimo Carlotto, At the End of a Dull Day, trans. Antony Shugaar (New York: Europa, 2013), 74. All subsequent citations refer to this edition.

${ }^{22}$ Famously in The Communist Manifesto, Marx describes how beneath or "veiled by religious and political illusions" lies "naked, shameless, direct, brutal exploitation."

Essential Writings of Karl Marx (St Petersburg, FL: Black and Red, 2010), 164.

${ }^{23}$ David Harvey, Seventeen Contradictions and the End of Capitalism (London: Profile, 2015), 53, 54.

${ }^{24}$ Pepper, Unwilling, 236.

${ }^{25}$ Berlant, Cruel, 15-16.

${ }^{26}$ See Ruth Leys, “The Turn to Affect”, Critical Inquiry 37 (2011), 434-472, 437.

${ }^{27}$ Brian Massumi, The Politics of Affect (Cambridge: Polity, 2015), ix.

${ }^{28}$ Anderson, “Affect”, 34.

${ }^{29}$ David Schmid argues that noir "is premised on in its opposition to all cultural and political orthodoxies.” Qtd. in Andrew Pepper, “The American roman noir” in Catherine Nickerson 
(ed.), The Cambridge Companion to American Crime Fiction (Cambridge: Cambridge University Press, 2010), 60.

${ }^{30}$ Leys summarizing Brian Massumi’s arguments in Parables for the Virtual. 'The Turn”, 441.

${ }^{31}$ Leys, “The Turn”, 441.

32 If we can tie the destructive potentialities of capitalism back to the revolutionary practices of the bourgeoisie (see The Communist Manifesto, chapter 1), what is particular about capitalism in its neoliberal phase, for my purposes, is the way in a privatization agenda and cuts to the welfare program resulting in widespread precarity that is felt hardest by the most vulnerable in society is reinterpreted as opportunity or freedom for the individual entrepreneur to sell his or her human capital without state stricture or intervention. For Anderson, Foucault's "Homo Economicus" is "a reorganisation of the liberal subject" through "processes of privatisation, personalisation and responsibilisation.” See "Affect", 38.

${ }^{33}$ See The Goodbye Kiss, 108.

${ }^{34}$ Lester K Spence characterizes the "neoliberal turn" and the implications for subjectivity in these terms. "These neoliberal ideas radically change what it means to be human, as the perfect human being now becomes an entrepreneur of his own human capital, responsible for his personal development.” Knocking the Hustle: Against the Neoliberal Turn in Black Politics (Brooklyn: Punctum, 2015), 113.

${ }^{35}$ Anderson, "Affect”, 39.

${ }^{36}$ Breu and Hatmaker, "Dark Passages".

${ }^{37}$ Massimo Carlotto, Death’s Dark Abyss, trans. Lawrence Venuti (New York: Europa, 2006), 137. All subsequent citations refer to this edition.

${ }^{38}$ Berlant frames this non-intentionality as follows: "Brian Massumi represents the nervous system as so autonomous that affective acts cannot be intended." Cruel, 14.

${ }^{39}$ Berlant, Cruel, 15.

${ }^{40}$ Sara Ahmed, “Affective Economies”, Social Text 79, Volume 22, No.2 (2004), 117-139, 119.

${ }^{41}$ Anderson, “Affect”, 39.

${ }^{42}$ Berlant, Cruel, 15.

${ }^{43}$ Massimo Carlotto, "Eulogy for Jean-Claude Izzo”, in Jean-Claude Izzo, Total Chaos, trans. Howard Curtis (New York, Europa, 2005).

${ }^{44}$ Berlant, Cruel, 15.

45 Berlant, Cruel, 16.

${ }^{46}$ Barbara Pezzotti, Politics and Society in Italian Crime Fiction: An Historical Overview (Jefferson, NC: McFarland, 2014), 166. 